\title{
Pembelajaran Sains yang Rahmatan Lil 'Alamin
}

\author{
Salafudin \\ Fakultas Tarbiyah dan Ilmu Keguruan (FTIK) \\ IAIN Pekalongan \\ Pekalongan, Indonesia \\ salafudin@iainpekalongab.ac.id
}

\begin{abstract}
Science and technology have great benefits for mankind. But science can also be a punishment for humans. In other words, science has positive and negative values for humans. Efforts need to be made to minimize the negative side of science and increase its benefits, so that science is present as a blessing for the universe. Science that is rahmatan lil 'alamin is a science that can implement the values of rahmatan lil 'alamen thus bringing humanity to a life that is prosperous, safe, peaceful and egalitarian. Such science is expected to bring harmony to life. Not only brings prosperity to humans, but also to all beings on earth.

Efforts to present the science of rahmatan lil alamien are carried out with science learning integrated with rahmatan lil 'aalmaien Islamic values. Science learning that rahmatan lil 'alamin has several characteristics, among others: presenting a non-pragmatic intention in learning science, linking faith to God with natural phenomena, science learning is contextual, science learning is associated with values, culture and beliefs.

The implementation rahmatan lil 'alamin science learning requires the hard work of all parties considering the current reality of science learning still oriented towards the West. This is due to the lack of concrete examples of learning models and alternative science books.
\end{abstract}

Keywords: Science Learning, Rahmatan Lil 'alamin.

Abstrak

Sains dan teknologi memberi manfaat yang besar bagi umat manusia. Namun sains juga bisa menjadi azab bagi manusia. Dengan kata lain, sains mempunyai nilai positif dan negatif bagi manusia. Perlu dilakukan ikhtiar untuk meminimalisasi sisi negatif sains dan memperbesar manfaatnya, sehingga sains hadir sebagai rahmat bagi semesta. Sains yang rahmatan lil 'alamin merupakan sains yang bisa mengimplementasikan nilai-nilai rahmatan lil 'alamien sehingga membawa umat manusia pada kehidupan yang sejahtera, aman, damai dan egaliter. Sains yang demikian diharapkan akan memunculkan harmoni kehidupan. Bukan hanya memunculkan kesejahteraan bagi manusia, melainkan juga bagi seluruh makhluk di muka bumi.

Upaya menghadirkan sains yang rahmatan lil 'aalamien dilakukan dengan pembelajaran sains terintegrasi dengan nilai-nilai islam rahmatan lil 'aalmaien. Pembelajaran sains yang rahmatan lil 'alamin mempunyai beberapa karakteristik antara lain: menghadorkan niat yang tidak pragmatis dalam mempelajari sains, mengaitkan keimanan kepada Tuhan dengan fenoma alam, pembelajaran sains bersifat kontekstual, pembelalajaran sains dikaitkan dengan nilai, budaya dan keyakinan. 
Implementasi pembelajaran sains yang rahmatan lil 'aalamin memerlukan kerja keras semua pihak mengingat realitas saat ini pembelajaran sains masih berkiblat ke Barat. Hal ini disebabkan minimnya contoh konkret model pembelajaran maupun buku sains alternatif.

Kata kunci: Pembelajaran Sains, Rahmatan Lil 'alamin

\section{A. Pendahuluan}

Saat ini negara-negara di dunia tengah berlomba-lomba untuk menguasai sains. Tujuannya adalah menguasai dunia, mengatur peradaban dunia atau sekurangnya menghindarkan dari dominasi pihak atau negara lain. Hal ini disebabkan, penguasaan sains dan teknologi penting bagi pengokohan eksistensi suatu bangsa dan negara. Negara yang mampu menguasai sains dan teknologi akan menjadi negara yang kuat baik secara sosial, ekonomi, militer maupun politik. Maka, sebuah negara kuat dan berpengaruh di masa kini pasti didukung oleh kekuatan sains dan teknologi. Kenyataan ini sejalan dengan ungkapan Alparslan Acikgenc, "When science is manifested in a new form of technology, it expresses itself as power; only that comunity in possession of that particular power that can dominate today's world (Ketika sains diwujudkan dalam bentuk baru teknologi, ia berperan sebagai kekuasaan; hanya masyarakat yang memiliki kekuasaan tersebutlah yang bisa menguasai dunia saat ini) "'. ..

Perlombaan penguasaan sains dan teknologi telah memberi berkah bagi umat manusia, berupa semakin maju dan berkembangnya sains dan teknologi yang membawa banyak kemudahan bagi hidup manusia. Namun pada sisi lain, ada dampak yang menyetainya. Dunia saat ini dihadapkan pada krisis multidimensi, yaitu sebuah krisis yang jangkauan wilayahnya mendunia, cakupan aspeknya beragam, dan mempunyai bobot permasalahan yang amat tinggi. Haidar Bagir dan Zainal Abidin dalam pengantar buku Filsafat Sains menurut Al Qur'an menyebut krisis tersebut sebagai krisis global ummat manusia ${ }^{2}$. Krisis-krisis tersebut meliputi krisis militer dan peperangan, krisis ekologi, krisis ekonomi, krisis politik, krisis moral maupun krisis kepribadian. Pada tataran nasional krisis multi dimensi juga muncul dalam bentuk maraknya korupsi, penyalahgunaan wewenang, konflik bernuansa sara, ekspresi kebebasan yang melampaui batas, maupun semakin meningkatnya para pelajar yang terlibat dalam tindakan pidana, seperti tawuran, penggunaan narkoba, pencurian, pemerkosaan, pergaulan bebas dan sebagainya. Dengan kata lain, sains dan teknologi bak pisau bermata dua, satu sisi membawa berkah sisi lain menebar ancaman. Sains dan Teknologi bukan hanya menjadi rahmat bagi semesta tapi membawa azab. Maka perlu dilakukan ikhtiar untuk meminimalisasi sisi negatif sains dan teknologi namun

\footnotetext{
${ }^{1}$ AlparslanAcikgenc, Islamic Science: Toward a Definition, Kuala Lumpur : ISTAC, 1996, hlm 3

${ }^{2}$ Haidar Bagir dan dan Zainal Abidin dalam Mehdi Golshani, Filsafat Sains Menurut Al Qur'an, Cetakan I, Bandung, Mizan, 2003
} 
memperbesar manfaatnya, sehingga sains dan teknologi hadir sebagai rahmat bagi semesta.

Upaya menguasai sains dilakukan dengan menyelenggarakan riset disamping pembelajaran di lembaga pendidikan formal. Maka upaya menghadirkan sains yang rahmatan lil 'aalamien dilakukan dengan pembelajaran sains terintegrasi dengan nilainilai islam rahmatan lil 'aalmaien. Tulisan ini bermaksud memberi tawaran pembelajaran sains yang rahmatan lil 'aalamien.

\section{B. Sains dalam Perspektif Barat Sains dan Islam}

Dalam perspektif Barat, Sains merupakan pengetahuan yang rasional empiris. ${ }^{3}$. Sains tidak mempunyai nilai, sains hanya memberikan benar atau salah, bukan baik dan buruk. Kenyataan inilah yang menyebabkan sains bersifat bebas nilai. Anggapan yang demikian tidak terlepas dari pandangan hidup sekuler (memisahkan agama dari urusan duniawi) masyarakat Barat. Paham sekuler ini dipercaya sebagai sebuah kemestian di dalam sains. Masyarakat Barat cenderung memandang agama bukan termasuk ilmu, melainkan dogma yang tidak memiliki pijakan dalam dunia empirik sehingga tidak dapat dipastikan kebenarannya. Bagi mereka tidak mungkin sains dan agama dapat menyatu.

Kecenderungan menyingkirkan agama dari sains tersebut terlihat pada pandangan para ilmuwan dan filosof kenamaan Barat ketika mendeskripsikan hubungan sains dengan Tuhan atau agama. Laplace (1749-1827), seorang matematikawan Perancis yang termasyhur, berpandangan bahwa Tuhan tidak perlu disebutkan dalam membahas persoalan sains, bukan karena ia memusuhi agama, melainkan karena tidak relevan. ${ }^{4}$ Ketika Napoleon bertanya kepadanya perihal Pengarang alam semesta yang ajaib ini kepadanya, Laplace menjawab, "Saya tidak membutuhkan hipotesis itu."5 Sementara itu Baron d'Holbach (1723-1789) meyakini bahwa alam materi merupakan satu-satunya realitas; tidak memerlukan penyebab eksternal (Tuhan) karena ia menciptakan dirinya sendiri. Tidak ada bukti adanya Tuhan, dan oleh karenanya semua individu berpendidikan dan rasional harus menolak agama sama sekali. Fisikawan d'Alembert (1717-1783) berkeyakinan bahwa tidak ada gunanya menyimpulkan eksistensi Tuhan dari alam, karena pengetahuan manusia tentang alam tidak lengkap ${ }^{6}$.

Filusuf Jerman, Immanuel Kant (1724-1804) mengakui bahwa Tuhan berada diluar jangkauan indra manusia. Manusia tidak bisa menyangkal atau membuktikan

\footnotetext{
${ }^{3}$ Ahmad Tafsir, Filsafat Ilmu, Mengurai Ontologi, Epistemologi dan Aksiologi Pengetahuan, Bandung, Rosda, 2010, hlm. 22

${ }^{4}$ Karen Armstrong, Masa Depan Tuhan: Sanggahan Terhadap Fundamentalisme dan Ateisme, Bandung, Mizan, 2009, hlm 374

${ }^{5}$ Ibid, hlm. 375

${ }^{6}$ Ibid, hlm 372
} 
keberadaan Tuhan karena manusia tidak memiliki alat verifikasinya. ${ }^{7}$ Charles Lyell (1797-1875), seorang ahli geologi, mengatakan agama dan sains adalah dua hal yang berbeda dan merupakan tindakan yang berbahaya untuk mencampur keduanya. ${ }^{8}$ Matematikawan Marie-Jean Caritat menyebutkan bahwa kecenderungan kepada teologi alam hanya membuang-buang waktu saja. ${ }^{9}$. Charles Darwin menyangkal penciptaan dunia, menyangkal bahwa manusia adalah ciptaan Tuhan. Menurutnya manusia terbentuk melalui proses evolusi trial and error dan Tuhan tidak punya campur tangan terhadap semua ini. ${ }^{10}$ Dan masih banyak lagi ilmuwan lain yang berpandangan serupa. Jadi terlihat epistemologi Barat menolak atau menentang keterlibatan metafisika, Tuhan, wahyu, agama maupun intuisi dalam proses menggali pengetahuan ilmiah. ${ }^{11}$

Polemik seputar netralitas sains, tidak luput dari perhatian para ilmuwan muslim baik dalam tingkat global maupun regional. Pada tahun 1970-an, terjadi dialog intelektual antara Mukti Ali (saat itu dosen IAIN Yogyakarta) dengan Ahmad Sadali (dosen ITB). Mukti Ali menyatakan bahwa sains itu netral sementara Sadali berpendapat sains tidak netral. ${ }^{12}$. Dalam pandangan Ahmad Tafsir, sains tidaklah netral. Sains bagian dari kehidupan, sementara kehidupan itu secara keseluruhan tidaklah netral. Paham sains tidak netral adalah paham yang sesuai dengan ajaran semua agama dan sesuai pula dengan niat ilmuwan tatkala menciptakan teori sains. ${ }^{13}$ Pandangan Tafsir sejalan dengan pemikiran Syed Naquib Al Attas yang menganggap ilmu sebagai sesuatu yang tidak bersifat netral. ${ }^{14}$ Ismail Fajrie Al Atas sepakat dengan Syed Naquib dan menyatakan, "ilmu dipengaruhi pandangan hidup, agama dan kebudayaan individu dimana ilmu tersebut merekat, maka benar ungkapan Syed Naquib bahwa ilmu tidak bebas nilai". ${ }^{15}$

Paradigma ilmuwan Barat yang menganggap sains netral bertolak belakang dengan pandangan hidup Islam. Di dalam Islam, alam merupakan jejak atau tanda kewujudan Sang Pencipta dan berfungsi sebagai ayat ayat Tuhan, sebagai alat komunikasi Tuhan dengan hambanya. Langit dan bumi serta segala isi di dalamnya merupakan ayat ayat kauniah, sebuah kitab terbuka yang dikarang oleh Sang Pencipta untuk menyampaikan pesan kepada hamba-hambanya seperti halnya al-Qur'an juga. Al-Qur'an berulangkali mengingatkan manusia untuk senantiasa memperhatikan

\footnotetext{
${ }^{7}$ Ibid, hlm 373-374

${ }^{8}$ Ibid, hlm 396

${ }^{9}$ Ibid, hlm 373-374

${ }^{10} \mathrm{Ibid}, \mathrm{hlm} 400$

${ }^{11}$ Mujamil Qomar, Epistemologi Islam, Jakarta, Erlangga, hlm 96

${ }_{12}$ Ahmad Tafsir, 2010, hlm 45

${ }^{13}$ Ibid, hlm 49

${ }^{14}$ Syed Naquib Al Attas, Risalah Untuk Kaum Muslimin, Kuala Lumpur, ISTAC, 2001, hlm.

${ }^{15}$ Ismail Fahrie Al Atas, Sungai Tak Bermuara, Risalah Konsep Ilmu Dalam Islam, Sebuah Tinjauan Ihsani, Jakarta, Diwan, 2006, hlm. 52
}

49 
ciptaan Allah yang ada di langit dan di bumi dan merenungkannya sehingga manusia menjadi semakin mengenal Tuhan. Bahkan al-Qur'an mengecam orang-orang yang gagal melihat kaitan alam dengan Allah dan menyebut mereka sebagai orang-orang yang buta, tuli, dan tidak berakal atau berhati serta meletakkan derajat mereka di tingkatan lebi rendah daripada hewan ternak (QS. Al-A'raaf : 179). Karena itu, bila ilmuwan Barat menolak Tuhan karena tidak ada bukti kewujudan-Nya, maka Islam justru melihat alam sebagai bukti yang paling kuat dan nyata tentang keberadaan Tuhan.

\section{Sains yang Rahmatan Lil 'alamien}

Kalimat Rahmatan Lil “Alamin merujuk pada firman Allah pada al-Qur'an surah al-Anbiyaa' ayat 107, yang berbunyi:

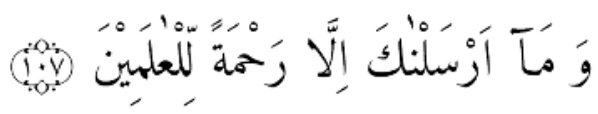

Artinya: "Dan tidaklah Kami mengutusmu (wahai Muhammad) kecuali sebagai rahmat bagi seluruh alam."16

Mengomentari ayat ini, Imam Ibn Katsir berkata: “Allah ta'ala mengabarkan bahwa Dia menjadikan Muhammad shallallahu 'alaihi wa sallam sebagai rahmat bagi seluruh alam. Maksudnya adalah, Allah mengutusnya sebagai rahmat bagi mereka seluruhnya. Barangsiapa menerima rahmat ini dan bersyukur atas nikmat ini, maka ia akan bahagia di dunia dan akhirat, dan barangsiapa yang menolak dan mengingkarinya, maka ia akan merugi di dunia dan akhirat."17

Sementara itu, Quraish Shihab menjelaskan bahwa, redaksi ayat di atas sangat singkat, tetapi ia mengandung makna yang sangat luas. Ayat ini menyebut empat hal pokok. 1) Rasul/utusan Allah dalam hal ini Nabi Muhamad saw., 2) yang mengutus beliau dalam hal ini Allah, 3) yang diutus kepada mereka (al-'alamin) serta 4) risalah, yang kesemuanya mengisyaratkan sifat-sifatnya, yakni rahmat $^{18}$ Rahmatan Lil 'Alamin, berasal dari gabungan dari tiga kata, yaitu Rahmatan, Li, dan al-'Alamin. Kata rahmat bermakna belas kasih ${ }^{19}$ Dalam Kamus Besar Bahasa Indonesia, rahmat artinya juga belas kasih, atau karunia Ilahi ${ }^{20}$. Sedang al-'Alamin

\footnotetext{
Syafi'i, 2004, 519.

${ }^{18}$ Quraish Shihab, Tafsir Al-Misbah, Jakarta, Lentera Hati, 2005, Cet. Ke-4, jilid, VIII, hlm. hlm 483

${ }^{19}$ AW Munawwir, Kamus Al Munawwir Arab Indonesia, Surabay, Pustaka Progressif, 1997,

${ }^{20}$ http://kbbi.web.id/ diakses 9 Oktober 2015 jam 13.01
}

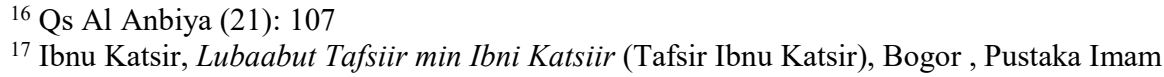


bermakna alam ${ }^{21}$ atau semesta. Dalam kamus besar bahasa Indonesia, alam beemakna segala yang ada di langit dan di bumi (seperti bumi, bintang, kekuatan), alam juga berarti dunia ${ }^{22}$ atau semesta. Semesta artinya seluruh; segenap; semuanya, semua yg ada di alam atau (berlaku untuk) seluruh dunia (universal. ${ }^{23}$.Dengan demikian rahmatan lil 'alamin dapat diartikan sebagai belas kasih atau kasih sayang atau karunia atau anugerah Tuhan bagi semuanya semua yang ada di alam semesta ini.

Ada dua domain dalam rahmatan lil 'aalamin, yaitu 1\} domain karakteristik yang dimunculkan dan 2) domain obyek rahmatan lil 'alamin. Karakteristik dari rahmatan lil'aalamin adalah jabaran dari sikap belas kasih dan karunia Ilahi. Belas kasih merupakan perasaan sayang, cinta, suka kepada sesama manusia, hewan atau benda. Sedang karunia Ilahi adalah anugerah, pemberian Tuhan yang harus disikapi dengan ungkapan syukur dan pengabdian pada Tuhan.

Implementasi sifat rahmat meniscayakan adanya nilai-nilai normatif untuk menerapkan sikap keadilan, kejujuran, persamaan, egaliterian, kebebasan, persaudaraan, musyawarah, yang kesemuanya itu dalam rangka mewujudkan suatu tata harmoni kehidupan masyarakat, bernegara dan hubungan antar negara yang sebaik-baiknya untuk kemaslahatan hidup yang berkesinambungan, baik kehidupan individual maupun kehidupa sosial dan hubungan dengan alam. Dengan demikian segala bentuk penindasan, penjajahan atau pun eksploitasi manusia terhadap manusia lain atau pun manusia terhadap alam merupakan perbuatan dlolim yang bertentangan dengan karakteristik rahmatan lil 'alamin.

Obyek rahmatan lil'alamin adalah seluruh yang ada di semesta, tanpa terkecuali, baik manusia dengan aneka ras, bangsa, negara dan agama maupun hewan, tumbuhan dan benda mati. Dengan demikian implikasi dari rahmatan lil 'aalamin adalah munculnya sikap mensyukuri karunia Tuhan dengan sikap pengabdian pada Nya, diikuti sikap empati, melindungi atau menyayangi semua manusia dan toleran terhadap perbedaan tanpa memandang ras, bangsa, negara dan agama maupun hewan, tumbuhan dan benda mati. Pada sisi lain rahmatan lil 'alamin menghindarkan munculnya sikap abai terhadap agama, dan sikap egois, menindas atau sikap merasa benar sendiri.

Sains yang rahmatan Lil 'aalamin adalah sains dimanfaatkan untuk menjadi karunia bagi semuanya, memberi manfaat sebesar-besarrnya bukan saja bagi kesejahteraan manusia namun juga bagi bagi terwujudnya harmoni kehidupan. Sains yang demikian tentunya sains yang tidak bebas nilai setidaknya pada sisi aksiologis, karena sains diarahkan berpihak pada maslahat dan tidak dibiarkan memunculkan mudlorot.

${ }^{21}$ AW Munawwir, Kamus Al Munawwir Arab Indonesia, Surabay, Pustaka Progressif, 1997, hlm 966

$22 \mathrm{http} / / / \mathrm{kbbi} . w e b . i d /$ alam, diakses 17 Oktober jam 23.00

${ }^{23} \mathrm{http} / / / \mathrm{kbbi} . w e b . i d /$ diakses 9 Oktober 2015 jam 13.05 
Sains yang rahmatan lil 'alamin dengan demikian merupakan sains yang bisa mengimplementasikan nilai-nilai rahmatan lil 'alamien sehingga bisa membawa umat manusia pada kehidupan yang harmoni, sejahtera, aman, damai dan egaliter. Sains yang rahmatan lil 'alamin diharapkan bisa menebalkan sikap religiusitas pada satu sisi diikuti sikap empati, sayang terhadap sesama makhluk dan toleran terhadap perbedaan yang muncul.

\section{Pembelajaran Sains Rahmatan Lil'alamin}

Pembelajaran tidak dapat dipisahkan dari penanaman nilai, sebagaimana dikemukakan oleh Fraenkel, "Teaching is value oriented enterprise. The teaching of value, in fact, is unavoidable." "24. Pelaku pembelajaran adalah manusia, lembaga, atau negara dan bangsa yang secara sadar atau pun tidak sadar memiliki tujuan tersurat atau pun tersurat memasukkan nilai dan kepentingannya.

Corak pendidikan yang selama ini dijalankan di Indonesia sangat dipengaruhi oleh pola-pola pendidikan yang diterapkan di Barat yang menurut Asad pengaruhnya bukan saja mungkin, bahkan sangat boleh jadi akan menimbulkan sikap anti agama dalam kehidupan para pelajar di masa akan datang. ${ }^{25}$ Sikap abai atau anti agama merupakan suatu bentuk ekstrimitas yang mungkin timbul akibat mal praktik dalam pembelajaran. Bentuk lain dari dari mal paktik pembelajaran adalah sikap berlebihan dalam memahami dan memandang persoalan dengan pendekatan teks secara sempit. Kedua ekstrimitas itu, tidak sejalan nilai Islam Rahmatan lil 'aalamien.

Di bawah ini kami akan menunjukkan beberapa hal harus dilakukan guna mewujudkan pembelajaran sains yang rahmatan Lil 'alamien.

\section{Niat Mempelajari Sains Bukan Pragmatis}

Umumnya, tujuan mempelajari sains bersifat pragmatis yaitu mengenal fenomena alam belaka yang tidak ada sangkut pautnya dengan agama. Tujuan mempelajari alam pada akhirnya disempitkan hanya untuk keperluan hidup seharihari dan kepentingan mengembangkan teknologi di masa depan. Sebenarnya tujuan duniawi tersebut bukanlah tujuan yang salah, sebab manusia tentu saja memerlukan pengetahuan tersebut. Jika ditanya mengapa para siswa harus mempelajari gerak benda, perambatan gelombang, energi, listrik-magnet, sistem tubuh manusia, seluk beluk penyakit, aneka tanaman dan tumbuhan, reaksi kimia, serta gerak matahari, bulan, serta planet, maka jawabnya adalah karena semua hal itu merupakan pengetahuan yang berguna bagi kehidupan mereka di dunia sehingga dapat menjamin keberlangsungan hidup mereka. Akan tetapi, tujuan tersebut tidaklah lengkap, karena hanya menyentuh fenomena permukaan yang bersifat empiris tanpa memberi peluang

${ }^{24}$ Jack. R Fraenkel, How to Teach About Values : An Analytic Approach, New Jersey : Prentice Hall, 1997, hlm. 1

${ }^{25}$ Muhammad Asad, Islam di Simpang Jalam, Bandung : Pustaka, 1983, hlm. 78 
pada hal-hal yang bersifat transenden. ${ }^{26}$ Mempelajari sains hanya pada dataran material, akan menghantarkan pada sikap hidup yang materialistis, pragmatis, transaksional bahkan egois. Hal ini berimplikasi pada penggunaan teknologi yang juga bersifat pragmatis, bahkan destruktif. Kasus kebakaran hutan, seabagai contoh adalah disinyalir disebabkan oleh sikap tamak sekelompok orang yang membakar hutan guna memanfaatkan lahan untuk kepentingan usahanya, tanpa mengingat keselamatan sesama.

Dengan menempatkan tujuan yang tidak pragmatis, bahkan bertujuan untuk mengenal Tuhan dalam mempelajari ilmu, diharapkan akan meminimalisasi sifat serakah, karena mengetahui eksistensi Tuhan bisa menjadi kendali. Apalagi dalam Islam ilmu dipelajari bukan demi kehidupan di dunia saja, tetapi juga bekal bagi kehidupan akhirat. Maka dari itu, semua pencarian ilmu dan amal perbuatan manusia haruslah mengantarkannya kepada pengenalan kepada Tuhannya, sebab hal inilah yang membawanya kepada kebahagiaan akhirat yang kekal. Karena itu, Islam tidak menjadikan kedua tujuan tersebut terpisah, tapi keduanya merupakan satu rangkaian yang tidak terputus.

\section{Mengaitkan Keimanan Kepada Allah dengan Fenomena Alam}

Sebagaimana diungkapkan di atas, salah satu karakteristik sains yang rahmatan lil 'alamin adalah mengakui salam semesta merupakan karunia Tuhan. Pengakuan terhadap karunia Tuhan ini diwujudkan dengan sikap mengabdi pada Tuhan. Sains yang rahmatan lil 'alamin mempertebal religiusitas. Mengkaitkan keimanan pada Tuhan dengan fenomena alam adalah suatu yang bisa dilakukan untuk meraih hal tersebut. Namun saat ini terdapat semacam keengganan untuk menisbatkan berbagai fenomena alam sebagai cerminan perbuatan dan kuasa Tuhan. Ini seakan-akan menegaskan pendirian Laplace dan ilmuwan Barat lainnya, sebagaimana telah disinggung sebelumnya, bahwa tidak ada perlunya menyangkutpautkan alam dengan keberadaan Tuhan sebagai Pencipta dan Pengatur alam. Sebab menurut mereka alam, sebagaimana gambaran Descartes, tak ubahnya seperti mesin besar yang bekerja berdasarkan hukum-hukum mekanika yang pasti. ${ }^{27}$ Setiap fenomena alam digambarkan sebagai peristiwa yang digerakkan oleh rantai sebab-akibat dan semua ini telah cukup sebagai penjelasan bagi semua fenomena alam. Maka, tidak ada perlunya menyebut-nyebut adanya kuasa atau taqdir Allah dalam setiap fenomena alam.

${ }^{26}$ AM Syaefuddin,. et. Al., Deseekularisasi Pemikiran Landasan Islamisasi, cetakan pertama , Bandung, Mizan , 1987, hal. 46

${ }^{27}$ Fritjof Capra,, Titik Balik Peradaban : Sains, Masyarakat, dan Kebangkitan Budaya, Yogyakarta : Yayasan Bentang Budaya, 1997, hlm. 62 
Sebagian orang boleh jadi akan berpendapat, "Jika semua peristiwa alam dikatakan sebagai kuasa dan perbuatan Tuhan, maka tidak ada lagi yang tersisa untuk dipelajari, dan karena itu mustahil sains dapat berkembang dengan baik". Pendapat ini tentu saja tidak tepat dan tidak pernah terbukti dalam sejarah dunia Islam. Sebab, ilmuwan Muslim di masa dulu juga melakukan melakukan hal itu, dan pada saat yang sama ilmu sains berkembang dengan sangat pesat. Ilmuwan Islam terdahulu tidak perlu menjadi atheis terlebih dahulu untuk bisa mengembangkan sains, bahkan agamalah yang menjadi pendorong mereka untuk tekun dalam meneliti alam.

Pada dasarnya sistem pendidikan nasional telah secara tegas menyebutkan bahwa corak pendidikan nasional bersifat religius karena menjadikan iman dan takwa serta akhlak mulia sebagai tujuan pendidikan sebagaimana dijelaskan dalam konstitusi dan perundang-undangan. ${ }^{28}$ Oleh karena itu aspek-aspek religius merupakan hal penting di dalam dunia pendidikan di Indonesia. Dalam bentuk yang rinci, tujuan pendidikan ini pun diterjemahkan ke dalam dokumen pendidikan yang lebih rendah. Sebagai contoh pada Standar Isi untuk Satuan Pendidikan Dasar dan Menengah yang dikeluarkan BSNP tahun 2006. Di sana dijelaskan bahwa tujuan diadakannya pengajaran IPA di tingkat SMP/MTs adalah Meningkatkan keyakinan terhadap Tuhan Yang Mahaesa berdasarkan keberadaan, keindahan, dan keteraturan alam ciptaanNya. Demikian juga kita dapat menemukan filosofi yang sama dalam penjabaran kompetensi inti dan kompetensi dasar Kurikulum 2013. Kurikulum 2013 menganut filosofi bahwa kompetensi inti setiap pelajaran selalu berkaitan dengan penghayatan dan pengamalan ajaran agama. Sebagai contoh, disebutkan bahwa bahwa kompetensi dasar pelajaran Fisika kelas X adalah bertambah keimanannya dengan menyadari hubungan keteraturan dan kompleksitas alam dan jagad raya terhadap kebesaran Tuhan yang menciptakannya. Maka dari sini jelas bahwa corak pendidikan sains di Indonesia semestinya tidak sekuler (anti agama) melainkan sangat erat terkait dengan nilai-nilai keagamaan.

Tapi kenyataan di lapangan yang terjadi justru tidak demikian. Hal ini dapat dilihat dari kandungan buku teks pelajaran IPA yang ada di semua jenjang pendidikan yang pada umumnya jarang sekali yang mengaitkan pelajaran IPA dengan nilai-nilai keagamaan. Hal ini berimplikasi pada pembelajaran sains kurang memberi kontribusi bagi pembentukan karater. Permasalahan dekadensi moral yang nota bene bertentangan dengan nilai rahmatan lil 'aalamin marak dikalangan generasi muda dalam bentuk tawuran pelajar, curanmor, maupun pergaulan bebas.

\footnotetext{
${ }^{28}$ Lihat pasal 31 ayat 3 Undang Undang Dasar 1945. Lihat juga pasa 3 Undang-Undang no 20
} tahun 2003 tentang Sistem Pendidikan Nasional. 
3. Meningkatkan Sikap Percaya Diri Para Pelajar Muslim dengan Memunculkan Buku Daras Sains Baru

Sikap rahmatan lil 'alamin meniscayakan adanya rasa kesejajaran sesama. Tidak ada dominasi suatu kelompok atas lainnya. Namun yang terjadi, pembelajaran sains di lembaga pendidikan saat ini cenderung mendorong munculnya sikap rendah diri pelajar muslim. Hal ini dsiebabkan jika kita perhatikan buku-buku teks pelajaran IPA saat ini, semua tokoh-tokoh ilmuwannya nyaris tidak ada yang beragama Islam. Kita tidak atau sangat jarang menemukan nama nama ilmuwan Muslim seperti alBiruni, Ibnu Haitsam, al-Razi, al-Khawarizmi, Ibnu Sina, Jabr Ibnu Hayyan, Ibnu Syatir, Nasirudin al-Tusi, al-Jazari, dan lainnya di dalam buku teks tersebut. Sebaliknya buku teks IPA kita dipenuhi dengan tokoh-tokoh (Barat) seperti Newton, Mendel, Snellius, Einstein, Galileo, Darwin, Maxwell, Kepler, Copernicus, Max Planck, dan banyak lainnya. Ketiadaan nama muslim tersebut,. Pada akhirnya hal ini menumbuhkan dan meneguhkan perasaan rendah diri kalangan muda Muslim di hadapan superioritas bangsa Barat karena mereka tidak menemukan teladan ilmuwan Muslim yang dapat menumbuhkan kebanggaannya terhadap Islam. Sebaliknya, mereka lebih bangga dengan segala sesuatu yang berbau Barat dan melakukan banyak peniruan terhadap cara hidup Barat.

Ketiadaan nama ilmuwan Muslim berikut karya-karya mereka di dalam pengajaran sains di sekolah tersebut secara perlahan akan menghapus jejak sejarah kegemilangan peradaban Islam di dalam ingatan para pelajar Muslim. Akibatnya mereka terputus dari akar sejarah mereka sendiri sehingga di masa depan mereka akan kesulitan mengidentifikasi diri mereka. Maka upaya mengembalikan rasa percaya merupakan sesuatu yang harus dilakukan, dengan menampilkan nama-nama ilmuwan muslim berikut karya-karya mereka dalam pengajaran sains di sekolah. Upaya ini dilakukan dengan memunculkan buku daras dalam pengajaran sains yang bukan semata mengadopsi buku buku yang sudah ada. Mengabaikan al-Qur'an dan Hadits Sebagai Sumber Keilmuan

\section{Pembelajaran Sains Bersifat Kontekstual}

Untuk mewujudkan sains yang rahmatan lil'aalamin, mempelajarai sains disamping untuk memahami teori tentunya mempunyai sisi aksiologis. Pengajaran sains sudah selayaknya ditujukan bagi terwujudnya tatanan kehidupan yang harmoni, keseimbangan lahir dan batin, bukan semata untuk pengembangan ilmu. Maka pengajaran sains harus dikaitkan dengan realitas kehidupan. Implementasi dari hal itu, sumber belajar sains bisa diambil dari alam sekitar dan dari fenomena kehidupan sehari-hari. Dengan demikian pembelajaran sains bisa memberi kontribusi dalam menyelesaikan problema masyarakat ${ }^{29}$

${ }^{29}$ Sagala, syaiful, 2012, Konsep dan Makna Pembelajaran untuk Membantu Memecahkan Problematika Belajar dan Mengajar. Bandung: Alfabeta, hlm. 3 
5. Pembelalajaran Sains dikaitkan Dengan Nilai, Budaya dan Keyakinan

Pembelajaran sains yang rahmatan lil 'alamin diharapkan akan membentuk kearifan lokal dan sikap mampu mengambil hikmah dari suatu peristiwa atau fenomena alam, sehingga bisa bersikap bijak terhadap sesama dan alam semesta. Maka pembelajaran sains, tidak terpaku pada tataran teknis, empiris positivistik namun juga bisa mengkaitkan dengan dengan keyakinan-keyakinan suprarasional dan tata nilai religius.

Pada kenyataannya, pengajaran sains di sekolah saat ini sangat jarang mengaitkan peristiwa alam yang dibahas dengan keyakinan-keyakinan suprarasional dan tata nilai kehidupan agama. Hal ini karena pemikiran sekuler senantiasa melihat alam sebagai rantai sebab akibat materialistik saja. Sains melalui metode saintifik-nya (scientific methods) dianggap sebagai satu-satunya penjelasan yang sah dan valid mengenai fenomena alam (scientism). Sebaliknya dalam pandangan Islam dan kultur masyarakat, kejadian-kejadian yang terjadi di alam seringkali terkait dengan bagaimana manusia menjalani kehidupannya. Allah Subhanahu wa Ta'ala telah berfirman;

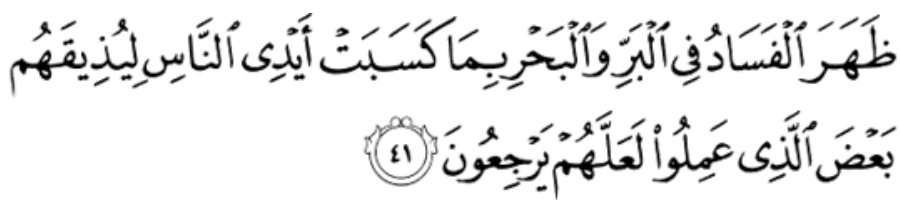

Artinya: Telah nampak kerusakan di darat dan di laut disebabkan karena perbuatan tangan manusia, supaya Allah merasakan kepada mereka sebahagian dari (akibat) perbuatan mereka, agar mereka kembali (ke jalan yang benar). ${ }^{30}$

Ibnu Katsir menjelaskan bahwa yang dimaksud dengan kalimat "Telah nampak kerusakan di darat dan di laut karen perbuatan tangan manusia" adalah terjadinya kekurangan tanam-tanaman dan buah-buahan disebabkan oleh kemaksiatan. ${ }^{31}$ Hal ini menegaskan padangan Islam bahwa kejadian-kejadian di alam bukan semata-mata timbul dari sebab-sebab kealaman saja. Tanpa mengabaikan sebab-sebab lahiriah (kealaman), Islam juga memandang peristiwa alam dalam pandangan bathin juga. Seorang yang beragama semestinya tidak memandang peristiwa banjir dan kekeringan di Tanah Air semata-mata karena adanya pengaruh fenomena el-Nino atau la-Nina di laut Pasifik, atau mewabahnya kebakaran hutan dan bencana asap karena kemarau panjang, atau kejadian gempa disebabkan semata-mata karena pergerakan lempeng bumi di sekitar lintasan Ring of Fire, tetapi juga

\footnotetext{
${ }^{30} \mathrm{QS}$. Ar-Ruum (30) : 41

${ }^{31}$ Ibnu Katsir, Lubaabut Tafsiir min Ibni Katsiir (Tafsir Ibnu Katsir) Jilid 6, Bogor : Pustaka Imam Syafi'i, 2004, hlm. 379
} 
melihatnya sebagai buah dari menyimpangnya manusia dari jalan Allah Subhanahu wa Ta'ala. Inilah yang dikatakan Umar bin Khattab ketika menanggapi terjadinya gempa di Madinah. Beliau mengatakan, "Jika terjadi gempalagi, saya tidak akan tinggal bersama kalian di sini". ${ }^{32}$ Maksudnya bila gempa kembali melanda, itu berarti telah banyak kemungkaran di Madinah, dan Umar tidak ingin lagi tinggal di tempat seperti itu.

Selain itu juga pengajaran sains yang rahmatan lil 'alamin juga perlu mengkaitkan fenomena alam dengan amal-ibadah atau akhlak. Misalnya, ketika membahas fenomena terjadinya gerhana matahari dan bulan, guru-guru sains tidak hanya fokus pada sebab-sebab terjadinya fenomena gerhana tersebut, tetapi dikaitkan dengan pelaksanaan ibadah. Biasanya, guru sains ketika mempelajari gerhana matahari atau bulan hanya semata mebahas secara teknis dan kausalitas terjadinya gerhana tersebut. Kalaupun ada anjuran, biasanya anjuran untuk menghindari melihat gerhana matahari secara langsung karena dapat menimbulkan kebutaan. Tapi jarang sekali fenomena alam ini dikaitkan dengan sunnah untuk banyak bertakbir dan melaksanakan shalat gerhana. Ketika guru membahas makanan sehat, biasanya adalah terkait dengan zat-zat berbahaya atau tidak sehat yang terkandung di dalam makanan tetapi jarang sekali mengaitkan dengan kewajiban umat Islam untukmemperhatikan kehalalan suatu makanan atau keharusan mengucapkan basmallah sebelum menyantap makanan. Sebagian orang, termasuk sebagian kaum Muslim, mungkin akan berpendapat bahwa itu bukan pelajaran IPA lagi melainkan pelajaran agama. Padahal di dalam Islam seluruh hidup ini adalah ibadah, dan karena itu seluruh aspek kehidupan ini tidak terlepas dari agama.

Akibat tidak mengkaitkan pembelajaran sains dengan konteks keyakinan, internalisasi nilai nilai religius atau nilai rahmatan lil 'alamin tidak maksimal tertanam pada siswa. Karena itu pendapat itu mesti kita koreksi, yaitu bahwa berdasarkan argumentasi yang penulis tunjukkan di atas maka pelajaran IPA justru semestinya terkait dengan pelajaran agama, bukan malah memisahkannya.

\section{E. Penutup}

Sains merupakan berkah bagi umat bmanusia, sekaligus bisa menjadi bencana. Agar menjadi berkah, sains tidak dibiarkan bebas nilai, melainkan diarahkan menjadi rahmat bagi semesta. Upaya menguasai sains dilakukan dengan menyelenggarakan riset disamping pembelajaran di lembaga pendidikan formal. guna mewujudkan sains yang rahmatan Lil 'alamien, maka ada empat hal yang harus diperhatikan yaitu: niat mempelajari sains untuk mengenal Allah dan ibadah, mengkaitkan keimanan pada Allah dengan fenomena alam, meningkatkan rasa pecaya

\footnotetext{
${ }^{32}$ Ibnul Qayyim al-Jauziyah, Kunci Surga : Mencari Kebahagiaan dengan Ilmu (1), Solo :
} Tiga Serangkai, 2010, hlm 503 
diri pelajar muslim dengan memunculkan buku daras baru dan pembelajaran sains bersifat kontekstual.

Implementasi pembelajaran sains yang rahmatan lil 'aalamin memerlukan kerja keras semua pihak mengingat realitas saat ini pembelajaran sains masih berkiblat ke Barat. Hal ini disebabkan minimnya contoh konkret model pembelajaran maupun buku sains alternatif. 


\section{DAFTAR PUSTAKA}

Ahmad Tafsir, Filsafat Ilmu, Mengurai Ontologi, Epistemologi dan Aksiologi Pengetahuan, Bandung, Rosda, 2010

Alparslan Acikgenc, Islamic Science : Toward a Definition, Kuala Lumpur, ISTAC, 1996

AW Munawwir, Kamus Al Munawwir Arab Indonesia, Surabay, Pustaka Progressif, 1997

Fritjof Capra,, Titik Balik Peradaban : Sains, Masyarakat, dan Kebangkitan Budaya, Yogyakarta : Yayasan Bentang Budaya, 1997

Haidar Bagir dan dan Zainal Abidin dalam Mehdi Golshani, Filsafat Sains Menurut Al Qur'an, Cetakan I, Bandung, Mizan, 2003

http://kbbi.web.id/ diakses 9 Oktober 2015 jam 13.01

Ibnu Katsir, Lubaabut Tafsiir min Ibni Katsiir (Tafsir Ibnu Katsir), Bogor : Pustaka Imam Syafi'i, 2004,

Ibnul Qayyim al-Jauziyah, Kunci Surga : Mencari Kebahagiaan dengan Ilmu (1), Solo : Tiga Serangkai, 2010

Ismail Fajrie Al Atas, Sungai Tak Bermuara, Risalah Konsep Ilmu Dalam Islam, Sebuah Tinjauan Ihsani, Jakarta, Diwan, 2006

Jack. R Fraenkel,., How to Teach About Values : An Analytic Approach, New Jersey, Prentice Hall, 1997

Karen Armstrong, Masa Depan Tuhan : Sanggahan Terhadap Fundamentalisme dan Ateisme, Bandung, Mizan, 2009

Muhammad Asad, Islam di Simpang Jalam, Bandung : Pustaka, 1983

Mujamil Qomar, Epistemologi Islam, Jakarta, Erlangga

Syaiful Sagala, Konsep dan Makna Pembelajaran untuk Membantu Memecahkan Problematika Belajar dan Mengajar. Bandung: Alfabeta, 2012

Syed Naquib Al Attas, Risalah Untuk Kaum Muslimin, Kuala Lumpur, ISTAC, 2001 
| SALAFUDIN | Pembelajaran Sains yang Rahmatan Lil 'alamin

Quraish Shihab, Tafsir Al-Misbah, Jakarta, Lentera Hati, 2005, Cet. Ke-4, jilid, VIII 